\title{
Humanity
}

\section{Filling the gaps}

\section{Leo R. Carroll, MD, MSc ${ }^{*}$}

The bus lurched to a stop. I exited on legs, still wobbly and waking up. Daybreak began to light the city skyline-mountain peaks loomed above the downtown high-rises that emerged from the water with their sunny tops. The smell of the ocean hung in the crisp spring air.

Piles of cardboard laid outside shop doorways, with the occasional foot poking out from underneath. Tim Hortons offered the only caffeine fix at this early hour, and others found themselves drawn to the light like moths to a flame: the blending of bleary-eyed people from both ends of the candle and from all walks of life.

A young, disheveled man seemed to be putting patrons on edge inside. Several elderly men who were drinking their morning coffee were the target of his verbal assault. He lost interest and stumbled back to his friend who sat sprawled and limp in the corner. His friend's bag was spread open with needles and syringes atop dirty clothes. I counted his breaths as I waited-roughly 10 per minute. No role for Narcan. I clutched my morning coffee, made for the exit, and climbed the hill to the emergency department (ED).

It was an early morning shift, and my first patient had been waiting for a few hours. Well known to the staff here, but he was new to me. I was visiting from another city, and everything was new, including Clayton. His one-liner was similar to so many of our patients: on the streets, often in a shelter, and addiction ruling their life. The collective sigh as they come back, yet again, during these colder months.

I fumbled my way through the blend of paper charts and the unfamiliar electronic medical record-so many visits - two in the past three days. Keywords scribbled across his recent charts: "daily IV fentanyl use. Declined social work."
My staff physician peeked at the chart. We made small talk having just met, and I commented on my morning commute, about the scene while getting coffee, and about the syringes peering from the young man's bag.

"They've saved a lot of lives at that Tims," he said very matter-of-fact, emotionless. He moved onto the next chart.

I suspected there was more to his comment. Context and backstory that he was not sharing with me-a patient, perhaps, maybe more than one. His words were curt, but they instilled a sense of gratitude and respect to the workers behind the counter down the hill, indicating that we are all in this together. An unexpected partnership.

Clayton was sprawled across the bed with a blanket pulled up over his head. My six-year-old son did the same thing to hide from monsters-I wondered what Clayton was hiding from. He looked comfortable. Relishing the warm, dry mattress no matter how stiff. A cart with wobbly wheels was stuffed with his worldly possessions that sat in the corner-black garbage bags spilled over the edges. Clay poked his head out from under the blanket. His eyes were weary and eyelids drooping, and he mumbled his words, seemingly fumbling over his tongue. His hair was black with speckled gray, and it was sheered shorter in some places than others. His skin dark, leathery, and cracked from years of hardship. The dirt under his nails, a seemingly permanent fixture as though they had never been clean.

That day, he said he wanted to go somewhere. He needed off the street. He wanted help.

He needed time to sober up, but we had a great team to get him where he should go. The social worker started in an hour, and they would work out the details. Maybe a

From *Department of Emergency Medicine, University of Ottawa, Ottawa, ON.

Correspondence to: Dr. Leo Carroll, Department of Emergency Medicine, University of Ottawa/The Ottawa Hospital - Civic Campus, 1053 Carling Ave, E-Main, Room EM-206, Ottawa, ON K1Y 4E9; Email: Icarr064@uottawa.ca

(C) Canadian Association of Emergency Physicians

CJEM 2020;22(2):263-264

DOI 10.1017/cem.2019.414 
shelter for a few days. Maybe, I thought, maybe, this would be the time he stayed clean.

Time passed, and my shift wound down. I connected with our social worker, and they explained that no shelter beds were available that day, but there might have been other options-Clayton would not stay; he walked out.

My walk to the bus stop brought me past the same storefronts as that morning. Most doorways were clear, vacant during daytime hours, with cardboard neatly stacked against the wall. In one doorway, I saw feet sticking out. I saw Clay's cart with those wobbly wheels. I recognized his dark brown boots with the sole half pulled off. He laid on his back with a hospital blanket pulled over his head just as he did earlier that morning. This time he looked less comfortable, and I imagined he longed for that firm, dry plastic mattress he had up the hill. It was probably the lure of the next fix that brought him back outside, back to his cardboard and plastic bag shelter. Or maybe he just got sick of waiting-waiting for a system that was failing him.

Three days later, another early morning shift on a rainy day. This time, Clayton was huddled in the corner of Tims, and he was doing his best to get comfortable and stay dry. His hospital wristband was still on from the day I first met him.

On my way out, I handed him a bagel and a coffee and said his name. He looked at me, confused-he did not remember me, but he was thankful. At least, for today, he was dry and warm, the goodwill of strangers and Tims offering a makeshift solution when the shelter was not an option-filling the gaps in our system. I wished him well and continued on my way, certain that we would see him again.

We offer what we can, and, sometimes, that is a sandwich and hard mattress. Our door is always open, but other doors remain closed. Not enough detox or shelter beds, under-resourced, underfunded, and the unrelenting feeling that we should be doing more. We chip away, one chart at a time, one person at a time, and, maybe, next time, they will stay for help-and, maybe, next time, we will have more to offer.

Keywords: Addiction, emergency medicine, homelessness, humanities 